\title{
THE SOCIO-ONTOLOGICAL ASPECT OF NOMADISM ANALYSIS: THE LIFEWORLD OF A HUMAN AND A FAMILY
}

\section{Hapon N. P., Karas A. F.}

\section{INTRODUCTION}

In the 1970-90's, the papers of J.-F. Lyotard, J. Derrida, J. Deleuze, M. Foucault, J. Baudrillard and others had a considerable influence on the way we think about identity issues. These authors launched a postmodern critique of science and went on developing the particular critical style previously proposed by F. Nietzsche. This is a genealogical way of historical philosophizing; centering on metaphorical operations of language; anti-positivist perspectives, which were based on particularism; leveling the universalistic and generalized claims of the dominant discourse. After all, the time of modernity has a metaphor for unwavering and continuity of knowledge and cognition. This metaphor expresses a tree with a strong stem and branches, a crown, huge roots. The Tree of Knowledge is a metaphor for the European science project of modernity. Here, identity is a spatial metaphor: "Man without identity is like a tree without roots". Identity is described in the concept of history, archeology, genealogy, rooting, eradication, etc. The constant increase in the speed of social contacts appearance, their surface resembles more nomadic wandering in the steppe than the sedentary life of the policy resident. Therefore, to outline socialization problems, we turn to two, in our view, interconnected concepts, entities of the subjective world that are always objectified. It is about the identity and nomadism of the person living in the present, in a society of simultaneous globalization/fragmentation. At the same time, traditional nomads, nomadic peoples, mobile residents of individual territories and states need their own research. Instead, it is also important to identify the "inheritance" of the "multiplied" stigmatized identities that have become the source of psychological and social nomadism on the border of the XX - XXI centuries. It is hard to disagree that the time of modernity, the "control society" gave rise to 
a number of stigmatized identities (isolated, assimilated, deviant, marginal, transgressive, asocial ones, etc.). Multiplying the classifications of deviant, delinquent, and asocial identity carriers has put modern science at a dead end. Moreover, there have been accusations of an era of postmodernity and the postmodern culture that allegedly gave birth to these "fallen" identities. Hence 1960-70's were marked by attention to the socialization of "prosocial" identity (social assistance and support, socio-psychological adaptation, sociotherapy of people and groups).

Where do the nomadic vectors of change in group identity originate from? The stigmatized identity "sprouts" through the family, a trauma of sorts as a large social group. It can be an isolated identity that is not linked to and accrues to socioculture. In this way or another, nomadism is born in a certain "isolation" of a person, a group from sociality. J. Deleuze and F. Guattare took the concept of rhizome from botany and introduced it as the opposite model to the tree's hierarchical structure. The concept of wood is a metaphor for them, compared to the modernist model of thought that develops through binary opposition. Rhizome is a plant that grows horizontally and takes root even on a rocky base. From its creeping shoots new plants are formed, which in turn also release shoots and the like, forming a discontinuous surface without depth. Therefore, the post-structuralist model is presented by the authors through the figure of rhizome. Deleuze contrasts the rhizome with a linearly ordered root system ${ }^{1}$. The rhizomatic modus presents a way of thinking that is the opposite of "the visible, vertical branching of the western trees of knowledge". Rhizome as a figure of thought is focused, non-hierarchical and indefinable. It is a middle ground without beginning and end, in a constant process of becoming. Deleuze concepts, images-concepts are used in philosophical theoretical constructs about contemporary nomadic subjectivity, for example, female subjectivity (in sociology and psychology it is a problem of female migration, its factors).

\footnotetext{
${ }^{1}$ Deleuz G., Guattari F. Rhizome.Paris: Minuit, 1976. P. 57.

${ }^{2}$ The same source. P. 58.
} 


\section{Nomadism and the design of the lifeworld of a new social execution}

R. Braidotti, an Honored Professor of Utrecht University (the Netherlands) borrows an image-concept of rhizome under the influence of J. Deleuze's "Rhizome", which he co-authored with F. Guattari, the psychotherapist, for describing nomadic subjectivity. The epigraph to her paper Nomadic Subjects is a quote from G. Stein: "It's good to have roots when you can carry it with you"3. The choice of epigraph for Braidotti is not accidental. Traditions of speech practices (discourses) are rooted in the deep layers of culture. The subject's "rootedness" in culture and migration experience (travels) was decisive in the creation of textual eras. According to Braidotti, rhizome reflects the political ontology of nomadism and sets the stage for a post-humanitarian research on subjectivity. Here, one can see the borrowing of another nomad nominally used in Deleuze works. Deleuze considered nomadic consciousness as an intention to cross borders and move regardless of destination. For Braidotti, nomadic consciousness is the awareness of the subject of the mobility of borders, the movement in search of placement.

Philosopher R. Braidotti uses the term "nomad" as a form of entry into the debate about the postmodern crisis of value. As a follower of Deleuze's views and post-structuralist theorist, she expressed her skepticism about the so-called "crisis" that cannot occur at the same time as the emergence of numerous socio-cultural movements, such as women's community initiatives in Western Europe in the last quarter of the twentieth century. In Patterns of Dissonance 4 Braidotti was critical of the postmodern perception of new images of the female as a prototype of multicenter, changeable and disparate identity. The concept of nomadic subjectivity prompts modern scholars to claim differences as a positive force. Braidotti is based on the Deleuze principle of multiplicity, which allows seeing the problem of taking into account multiple substructures: nationality, race, age, lifestyle and social status under a certain universal structure (for example, "a woman"). Changes in the historical situation, the emergence of a

${ }^{3}$ Braidotti R. Nomadic Subjects. Gender Studies. Kharkov: KhTsGI. No. 4. P. 18.

${ }^{4}$ Braidotti R. Patterns of Dissonance: A Study of Women and Contemporary Philosophy.Cambridge: PolityPress, 1991. 326 p. 
postmodern transnational economy, underpinned by the migration process, encourage the development of new styles and forms of representation of universal concepts and identities.

In the Posthuman (2013), R. Braidotti represents the multiplicity of the image of a human in the time of globalization and fragmentation, increasing influence on the human psyche, information and biological technologies. Such loss of unity of the perceived subject should not dissuade the researcher. The Posthuman helps us understand the "meaning of our flexible and multiple identities" . The Posthuman expresses the transformations of human subjectivity and physicality, under the influence of a market economy, commercialization, the production of genetically modified organisms, which are slowly and gradually blurring the categorical differences between humans and other species of the living. Current time presents a number of changed types of identity of "a pilgrim" ("a dreamer", "a whore", "a tourist", "a player"), which are different nostalgia of nomadism. The concept of "a nomad" as a key subjectivity is now considered in Transpositions: On Nomadic Ethics (2006) by R. Braidotti. It adapts this concept to the previously developed rhizome concept by J. Deleuze and F. Guattari. The social aspect of nomadic subjectivity analysis brings the researcher closer to the phenomenon of female emigration. Here the nomadism of groups is not merely a transformation of identity, but also expresses a certain feminine lifeworld. The content of the concept of "lifeworld" is a response of a human to the diversity of social challenges. Human lifeworld is a world of human frankness (feelings, aspirations, desires, doubts, instructions, memories of the past and anticipation of the future, etc.). E. Husserl's concept of lifeworld had a significant impact on the philosophy of the twentieth century, on the becoming of existential-phenomenological studies of "early" M. Heidegger, the phenomenological sociology of A. Schütz, early variants of hermeneutics by J. Deleuze, J.J. Derrida, etc.). Human lifeworld as a general representative of a certain social harm not only reflects the social reality of globalization and economic transnationalization, but also outlines the course of action for its change. According to A. Schütz, being an inner world lifeworld functions on two principles.

${ }^{5}$ Braidotti R. The Posthuman. Cambridge: Polity Press, 2013. P. 67. 
In compliance with the first one, a human is an observer of social reality, according to the second one, a human is subjected to retention and regulation by existing social and cultural structures ${ }^{6}$. J. Habermas, the social philosopher, the author of the theory of communicative activity, noted that lifeworld is often in contradiction with the systemic world, suppressed by it. "The political system provides loyalty in a constructive and selective way. In the first case, it puts forward the social programs at the state level, in the second one it eradicates certain topics and ways of communication from public discussions. The latter is achieved through the social and structural filters of access to the formation of public opinion, or deformation of structures of public communication through bureaucratic methods, or manipulation of information flows ${ }^{7}$. The access to the resource of knowledge, the practice of constant retraining, mastering skills without prospects for implementation is equally problematic and it which leads to the formation of nomadic subjectivity, migration of a human.

The beginnings of the formation of one-person cultural and economic formation (class, stratum, etc.) were considered by Douglas Coupland, the Canadian writer, who spent some time in Italy and Japan, in the novel Generation X: Tales for an Accelerated Culture (1991). He was one of the first to describe such an execution, calling it "space poverty", which travels continents and countries in search of new impressions and is interrupted by accidental earnings. This group has the self-social anger (rage), a certain measure of "rebellion" against the lifestyle and values of the middle class.

The term "precariat" is a neologism, coined by the combination of the words "precarious" (Latin - "unstable") and the word "proletariat". Any community includes a part of the citizens, which can be called a precariat. K. Dörre, the Professor of the University of Jena, notes the decline of the "middle class" and the growth of the precariat in Germany in his numerous explorations and interviews. At that time, tens of millions of people in Ukraine belong to precariat, its mass is replenished by young people. G. Standing, one of the modern

${ }^{6}$ Schütz A., Lukman T. Life Structures; [translated by V.I. Kebuladze]. Kyiv: Ukrainian Center for Spiritual Culture, 2004. P. 18-19.

${ }^{7}$ Habermas, Yu. The Idea of Legitimation of Late Capitalism, Moscow: Praxis, 2010, p. 67. 
British social economists, characterizes a precariate person: on the one hand, it is a human who has no basic guarantees of life support (employment, housing, full value nutrition, acquisition of professional skills). On the other hand, the person of the precariat relies only on direct monetary remuneration, not counting on retirement, unemployment assistance, etc., because this human has no professional identity ${ }^{8}$. A typical precariat is a person living on the poverty line. Nowadays these are millions of young people with higher education and no confidence in the future, people who work in depressive jobs with difficult conditions of work, "disabled" and migrants. In addition, the frustration caused by the lack of the solution of this problem can intensify the words of condemnation by politicians and representatives of the "middle class", which hint at laziness, public irresponsibility, and lack of purpose as a result of these experiences in the inner world, the social anger fills. The latter is a timer rational factor that radicalizes social movements.

Strategy transformation of the lifeworld of a precariat human to a lifeworld, which is built on the inalienable, spiritual relations with the individual and his social environment must include not only moral requirements and socialization strategies. In the Ukrainian context, it is significant not only to reinforce human's responsibility, but also the reach of a human to the key assets of modern society. It is the splendor of time, space, knowledge. Time quality is one of the exclusive assets, but access to this resource is unequal for all people. We agree that time is duration, speed deployment processes, their pace and rhythm. A precariat human does not have a sufficient possibility to control the events of their own life temporarily. Time on a meager leisure is restricted in terms of unemployment. There is a need to take the time to overcome a variety of social barriers (such as bureaucratic one), to find and choose an alternate temporary workplace. Representatives of the "middle class" have access to a higher quality space, which provides individual autonomy, comfort and promotes self-realization. Instead, the person from the precariat is in a compacted social space (small-size housing, public transport, etc.). Such person is experiencing a reduction in the objects of "public domain" (parks, libraries, etc.). Business and commerce (street cafes)

${ }^{8}$ Standing G. The Precariat: The New Dangerous Class.London: Bloomsbury Academic, 2011. P. 56. 
capture and fence off public space for architecture, sculptures, fountains, making it inaccessible to precarious people. The access to resources, the practice of constant retraining, mastering skills without prospects for implementation is equally problematic.

Nomadism today characterizes any execution, including women. The ontological aspect of the analysis of female nomadism shows that it is a response to ageism and at the same time the desire to fulfill needs, which gives rise to information and communication socioculture of the present. The content of the concept of "lifeworld" can be considered broader than the content of the concept of "everyday life", is a spiritual response of the person to all the diversity of "challenges", globalization/fragmentation of groups, trends of identity/nomadism. Such multiple content of different senses of the human life is a conceptual benchmark for theoretical modeling of social reality. Philosophical reflection on the women's life is on time.

\section{Eradicating life resources of social groups: migration of family members, female ageism}

Life is a complex synthesis of personal, cultural, social elements. Each element is associated with models of interpretation or a phonetic representations of culture and its impact on action, the corresponding patterns of social relations (about society), what people are (about personality), and in what way they should act. Identity, in particular female one, reflects complexity, incompleteness, fragmentation in the world which has recently become globalized. Z. Bauman notes that "We need to prepare for a long period, which is characterized by a multitude of questions and a few answers, a variety of problems and sketches of their solutions, as well as to mediate between the chance of success and failure"9. No matter how complex the world is, the single-mindedness of the concepts of "identity/nomadism", their dynamism can be suppressed. It is possible to enhance identity through the civil responsibility of a person, a group. Responsibility rests with the individual because of the fact that he or she belongs to a particular community. "No moral individual or personal norms will ever remove our collective responsibility. This indirect responsibility

${ }^{9}$ Bauman Z. Retrotopia. Warszawa: Wydawnictwo naukowe PWN SA, 2018. S. 280 . 
for the things we have not committed, the consequences of what is no fault of ours, is our payment for the fact that we live not in ourselves but among other people... "10. Every government takes responsibility for the actions and wrongs of its predecessors and every nation takes responsibility for the great acts and wrongs of the past. In this sense, H. Arendt notifies that "we are always responsible for our parents' sins and reaping the benefits of their services"

The family is the most significant institution of socialisation. The establishment and self-realisation of a personality happens there. The family also performs such important functions as guardianship and care, socio-psychological protection and adaptation of the personality in crisis conditions. The modern Ukrainian family and its functions are characterised by conflicting tendencies, which influence the changes and development of relationships in the society as a whole and also the socio-cultural intentions of a young person. During the 20th century difficult, often destructive socio-political processes took place, which caused changes in the values of the Ukrainian family. The beginning of the $21 \mathrm{st}$ century was characterised by a strengthening of globalisation influences and migration processes, which noticeably transformed family values. Globalisation technologies present a new system of values of self-realisation ofthe personality, which has an impact on the traditional, spiritual-moral basis of thefamily. The time and energy spent on the use of new informational and telecommunicationtechnologies is increasing, while the sphere of emotional and spiritual communicationamong the family members becomes narrower. Authentic family relationshipsbecome weakened by migration which leads to the functional existence of a youngperson and produces social hostility and loneliness.

Modern Ukrainian researchers study different aspects of the influence of social, political, economic and other factors on the migration of Ukrainian families. Thereis a need to analyse more completely the reasons for the work-related migration ofUkrainian family members in order to trace the ways of overcoming the negativeconsequences of migration. The chosen topic is of urgent importance. The aim of theresearch is to analyse the impact of socio-

10 Arendt H. Odpowiedzialność $i$ władza sądzenia, tłum. Wojciech Madej, Mieczysław Godyń Warszawa: Prószyński i S-ka, 2006. S. 217.

${ }^{11}$ The same source, S. 208. 
economic and socio-psychological factors onUkrainian family members' migration and the ways of overcoming the crises whichprovoke it.

Over the centuries basic family values, such as spirituality, accord, welfare, parenthood-motherhood and patriotism have been crystallizing in the national culturalself-consciousness. A historical excursus into the early and middle parts of the 20th century points to the socio-political reasons for the decay in family values, such as thedestruction of its spiritual and religious basis by the Bolshevik regime; elimination ofthe economic basis of the family, i.e. private property; destruction of the family byfamine, mass murder of "class enemies", thus the increase in the number of homelesschildren and state "conveyerisation of upbringing". In the second half of the 20th century the deformation of Ukrainian families' basic values continued through suchprocesses as atheism propagation and replacement of the national family traditionswith the surrogates of the "soviet ritualism". Youth migration was artificially createdthrough the forming of a "rolling stone" psychology. The proletarization of the familyincreased: urbanized families became completely dependent on the state. Familyhealth deteriorated because of the ecological catastrophes (e.g. Chernobyl, chemicalpollution, etc). At the beginning of 1960s and over the next twenty years the averageUkrainian family consisted of four people - father, mother and two children. In 1990sthis index began to decline. And although during the last two or three years the birthrate has increased a bit, its growth has been insufficient to keep Ukraine from beingcalled "the country of one-child families".Processes of women's emancipation, which occurred earlier in Western Europe, also produced changes in the traditional family state. Ukraine supplies a substantial quantity of illegal emigrants, mostly between the ages of 30 and 45 . Ukrainian women more often declare (as evidenced by many sociological polls and much psychological research ${ }^{12}$ their readiness to take up a career or to migrate, putting off marriage and children.

Ageism is a significant circumstance of the work-related migration among middleaged women who leave their families. Globalisation and integration processes in all spheres of human

${ }^{12}$ Gerasimova T. "In a Different Voice": in Search of a Lost History. Gender Studies. Kharkov: KhCSI. 2000. Issue 4. pp. 227-246. 
activities gave Ukraine a great opportunity of entering a global labour market. On the other hand, those processes caused redistribution of working potential in the internal labour market. Hypertrophy of the national labour is an internal factor, which forces Ukrainians to migrate abroad in search of work. During the last ten years, the problem of social adaptation of certain population groups, dealing with the age category, has been more often discussed in psychological research on gender ${ }^{13}$. In addition, the problem of social disadaptation and economic dependence of women at the age of $40+(10$ years $)$ is almost not noticeable. Social "ageism" is the basis of personal problems and migration, which are faced by most women of this age category. Ageism is typically displayed as a limit on access to resources and the release of certain population groups from the participation in creating solutions. It happens most often that women of this age group have difficulties in adapting to dynamic social relationships of the competition-trade type. Under the influence of the social image of "Age", typical female roles, such as self-education, professional activities, child-rearing and family duties, are transformed into significant social and workingpositions. Personal problems of "social demission" and "deprivation of individuality status" are typical for a significant number of middle-aged women, who usually have secondary education and good professional qualifications. The marginal position of middle-aged women (prior to retirement age and their so-called "social old age") is caused by a range of objective and subjective circumstances, such as:

- strengthening of production relations of a competitive type in the sphere of female employment;

- specific policies in the sphere of state budget financing, where the great majority of women are employed (education, culture, medicine);

- disposition of 40-45-year-old women to give preference to the conservative (socialistic, soviet) forms of motivation over the creative types of employment and for the passive forms of organisation of their professional careers.

Age is a hidden reason for women to leave creative trades demanding high qualifications. Lack of work or low income causes

13 Hapon N.P. Gender in humanitarian discourse: a philosophical and psychological analysis. Lviv: Litopys, 310 p. 
the economic dependence of women and the low level of their future pensions. In order to survive women enter the system of secondary occupations in low-status, unregistered jobs in low-paid working places and completely depend on their employers. Such work intensifies the psychological feeling of marginality in women and their economic dependence and puts them into the group at risk. Women easily become potential victims of trafficking, alcoholism and homelessness etc.

The majority of women applying to the state employment service are women office workers between the ages of 40 and 45. This ageism is not based on any reason, besides the negative stereotypes of social perception. According to the psychological polls, many women are ready for complicated jobs; they have a high level of business leadership and are ready to change old professional settings.

As we can notice, none of the project tasks are directed at changing the psychological components of "women ageism". The psychological varieties of social rehabilitation for middle-aged women, on the one hand, do not refer to the necessary directions of social reforms, or on the other hand, to the directions of state support for their business activity. If, according to the poll data, almost half of middle-aged women are either unemployed or are in danger of being fired, there is an increased role for at least their psychological support (retraining, consultations etc). Therefore, workers of the state employment services and different funds should introduce as soon as possible into their perspective plans of work the development of activities promoting the psychological adaptation for women of this age category.

There also appears a necessity of country regulation of the factors, which cause migration processes of the young families' members. State policy, even at the financial level, can lower the mobility situation of members of young families in search of work and money for supporting a family with a new-born baby. However, a financial payment after the child's birth has a non-durable effect. Financial support for youngfamilies must be supplemented with the forming of civil consciousness in the growing youth, i.e.: a necessary return to an understanding by people of the meaning of life (what is the good of earning money if direct relationships with the family are lost?); realisation of the necessity of having children and rearing new 
generations who have to become better than their ancestors and have confidence in the future. Means of financial encouragement must play only a supplemental role. At the same time, we have to face the issues of how to improve living standards and what should be done to correct the demographic crisis. With regard to the latter, we must first work to provide qualitative social services and then to increase the birth-rate. The main role belongs to the spiritual and cultural policy of the state, from which economic and demographic policy will flow.

Can enlightening-explaining work influence the demographic situation and migration? Of course, propaganda promoting the family and a healthy life style can influence the demographic situation and decrease the migration desire of members of young families. However, this propaganda has also an additional function here to provide a strong world view basis and given an understanding of the meaning of life and one's own role in the stream of being. This must involve the beginnings of enlightening-upbringing work to form the family psychoculture of the young members of society. The problem lies in the fact that the values of the Ukrainian family have gone through many transformations ${ }^{14}$. Today in mass media as well as in everyday communication the most important link in the chain of being is lost, according to which the human life consists not only of work but of the family as well. In this case we have to work with children as well as with their parents and with youth. In this situation different educational and informational programmes for children and adults can be helpful. There are different learning programmes and methods of work, especially interactive programmes for children in the form of play, and special programmes for juveniles. It is important that the family, society, institutions and mass media participate in the complex task of upbringing. A special meaning nowadays is given to information from radio, television, Internet etc. It must propagate family values and give information that positively supports the family and the child. Today, the main effort for reducing the migration of Ukrainian families is put on the realisation of the project of demographic development.

${ }^{14}$ Hapon N. The Ukrainian Woman and Her Horizons: A Narrative Analysis of Student Essays. Psychological dimensions of culture, economy, management: Materials of the conference as of 12 March 2018; editor-in-charge O.M. Lozynsky. Lviv. 2018. Issue XI. P. 95. 


\section{The Negative Consequences of Female Nomadic Subjectivity: Loss of Happiness and Maladaptation}

Dynamics of social life, globalization and migration processes have their negative consequences. These are conflicts that arise in formal and informal groups, existential frustrations, intensification of mental and other overloads that provoke individual's maladaptation, which is social, professional, and personal. Psychologists also underscore the gender specificity of maladaptation. It is predetermined by the fact that the processes of socio-economic transformation in Ukraine have adversely affected the financial status of men and women. On the one hand, the reorganization or liquidation of many businesses, on the other hand, low wages caused social people's maladaptation. In its turn, social maladaptation is reinforced by the psychological component of professional marginalization (a sense of need for personal professional knowledge, skills, and abilities) that has led to labor migration for female, particularly middle-aged women (40-60 years old). Instead, in middle adulthood, social responsibilities increase when one is responsible not only for themselves but also for others, performing a number of important social roles (wives, mothers, daughters, sisters, colleagues). Psychology explores the problems of maladaptation, which depends on: a) the social context of socioeconomic change; b) conditions and nature of work, professional competence, prospects for the specialist's growth. However, current social circumstances indicate that psychological factors of maladaptation should be explored, taking into account gender and age characteristics of the individual.

Contemporary papers illuminated tendencies to consider happiness as a personal and social phenomenon; in particular, there is a tendency of transition of happiness analysis from the sphere of an individual to the sphere of group feelings (citizens, women, couples, etc.), their ideas of happiness. Happiness is a psycho-emotional state of the highest satisfaction with life, a sense of fullness and meaningfulness of being, a deep satisfaction and joy. Thus happiness meets the fulfillment of its human vocation.

The preparation of young people for adulthood as community members is carried out by social institutions, which should be based on the values and ideas of a European democratic society: human rights, equality, peace, social justice, democracy, individual freedom, 
security of citizens, interdependence, pluralism, cultural diversity, openness, responsibility, partnership, respect for the environment. The system of the values has been implemented in civic life and provides the concept of "a happy life". Subjective notions of happiness are at the heart of regulation of social behavior and professional activity. Afterall, the subjective idea of happiness reveals the often overshadowed features of the social development of the individual, the community as a whole.

In recent years, the problem of personality happiness has been actively researched in psychology. In general, we can outline certain areas of research: positive emotions and a subjective sense of happiness (for example, pleasure, lifesatisfaction, sense of closeness, constructive thoughts about yourself and your future, optimism, confidence, energy, lifeforce); positive personality traits (wisdom, love, spirituality, honesty, courage, kindness, creativity, sense of reality, search for meaning, forgiveness, humor, generosity, altruism, empathy, etc.); social structures that promote happiness and personal development (democracy, healthy families, free media, healthy workplace environment, healthy local social communities).

The problem of happiness over the past decades has been addressed by researchers and representatives of various theoretical areas. The main focus was humanistic psychology, which reliedon the achievements of G. Allport, A. Maslow, and K. Rogers. The conditions of happiness of personalwell-being (O. S. Stepa) were studied; factors of happiness (M. Argyll); perceptions of provincial youth about happiness in the context of emotional and motivational orientation (S. Zhubarkin); psychosemantic analysis of ideas about happiness of Chinese and Russian students (N. V. Vynichuk), female (S. I. Maslakov); humanhappinessas a socio-cultural phenomenon (A. Shamsetdinova); socio-philosophical analysis of the phenomenon of happiness (E. Mishutina); psychology of happiness and optimism (I. Jidaryan); felicity of modern youth (N. Kachur), etc.

Researchers O. Lipovska, N. Lavrynenko, O. Ivanova, V. Stets and others addressed the problems of women's emigration and women's ageism (dismissal from professional work, double standards when hiring) as indicators of social maladministration. They also pointed to the need for re-adaptation of the personality (restructuring of their behavior, changes in previous forms and way of life). 
S. Lyubomirsky, R. Dickerhoof, J. K. Boehm and K. M. Sheldon ${ }^{15}$, foreign researchers, addressed to find out the peculiarities of personal and socio-psychological factors (lack of professional employment, unstable financial situation, presence of internal discomfort, specifics of perception of one's own health, family, others, one's future, society), which predetermine maladaptation, reduce personal happiness.

Weakening of social identity, link to different social groups, centers, friends, family members of women returning from labor migration is obvious. The weakened identity leads to a sense of isolation being detached, which is exacerbated by the loss of specialty work, difficulties in employment. These difficulties have a social, institutional context. M. Seligman, a well-known researcher, admitted that at least three groups of factors influence a person's happiness: positive emotions (for example, pleasure, satisfaction of life, feeling of closeness, constructive thoughts about themselves and their future, optimism, self-confidence, energy, "vitality); positive personality traits (wisdom, love, spirituality, honesty, courage, kindness, creativity, sense of reality, search for meaning, forgiveness, humor, generosity, altruism, empathy, etc.); social structures conducive to happiness and human development (democracy, healthy families, free media, healthy workplace environment, healthy local social communities) ${ }^{16}$.

Theorists and practitioners apply their scientific method to study and determine the positive development of human potential, happiness. According to M. Seligman, the latter, is achieved through the realization of the aforementioned components (positive emotions, interaction with others, close interpersonal relationships, life meaning and own achievements), contributing to the qualitative and complete spiritual life of a person as a social being. Most life plans are initially organized in a person's mind. A person's belief in self-efficacy shapes the types of life scenarios associated with self-realization and social (personal, professional) success. Those with high self-efficacy

${ }^{15}$ Lyubomirsky S., Dickerhoof R., Boehm J. K. \& Sheldon K. M. Becoming happier takes both a will and a proper way: An experiment alongitudinal intervention to boost well-being. Emotion. 2011. No 11. P. 391-402.

${ }^{16}$ Seligman M. Authentic Happiness: Using the New Positive Psychology to Realize Your Potential for Lasting Fulfillment. New York: Free Press, 2004. P. 145. 
embody successful scenarios that provide positive support for the activity. Therefore, in terms of psychological assistance (psychotherapy) with maladapted women, it is appropriate to apply cognitive techniques that contribute to events prediction skills, develop ways of managing factors that affect life. Individuals with high self-efficacy set goals for themselves and apply analytical thinking, achieving high levels of professional performance. It is well known that human activity is purposeful, governed by a goal. A personal goal is determined by the influence of self-esteem, ability. The higher the self-efficacy is the higher goals the person sets for himself. Self-efficacy affects each of these cognitive motivators, explaining reasons (causal attribution), expecting results, and achieving goals. People with high self-efficacy explain their failures (attribution) with insufficient effort, and consider them as situational ones. Instead, those with low self-efficacy explain it with the low level of their skills. When a person is expected to have high results and low self-efficacy, it can cause depression. Some researchers have noted that reducing dissonance (as people explain certain events) affects self-efficacy ${ }^{17}$. Emotionally stable people with higher self-efficacy find it easier to tackle complex tasks and activities. Low self-efficacy causes depression and anxiety. People who set standards of selfpunishment and judge themselves cannot escape depression and feel unhappy.

Social workers working in women's organizations and centers should conduct trainings to improve self-efficacy and strengthen women's belief in their own resources. In addition, it is necessary to carry out preventive work with women mothers to reduce their migration aspirations and to shape personal involvement in the upbringing of children. The problem of readaptation through the improvement of women's self-efficacy is gradually being solved within various social projects. At present, the psychological types of social rehabilitation for middle-aged women are insufficiently attributed to the necessary areas of social reforms, on the one hand, and to the directions of state support on the other hand.

${ }^{17}$ Lyubomirsky S., Dickerhoof R., Boehm J. K. \& Sheldon K. M. Becoming happier takes both a will and a proper way: An experiment allongitudina lintervention to boost well-being. Emotion. 2011. No 11. P. 391. 
Therefore, personal self-efficacy can shape the lifeworld and is a significant life resource. It influences the activities of people, the choice of relationships with the environment. This choice develops different competencies of individuals, interests and social, interpersonal relationships. Violation of social identity, resulting from the loss of self-efficacy, leads to a weakening or even destruction of a family, marriage and family ties, interpersonal conflicts, suppression of gender-role identification. Consequently, migration is often a cover-up, masking the loss of the spiritual resources of the inner world of family members, in particular women (mothers, wives). They declare the desire to earn money and are open to the nomadic movement. Life becomes tougher; women discover masculine genderlike traits, namely, autonomy, determination, activity, perseverance, energy, and in some cases aggression and autonomy from close emotional ties with their own family members (with parents, husband, and children). Gender role changes the feminine life. A woman masculinates through difficult living and working conditions, experiencing a weakening of feminine gender identity, which is directly related to the identity of a wife and a mother. The consequence is not only social maladaptation and disharmony of family relationships, but also the feeling of being unhappy. This is due to the mismatch between socially conditioned, forced masculine behavior and inner femininity.

\section{CONCLUSIONS}

The social aspect of nomadic subjectivity analysis brings the researcher closer to the phenomenon of female emigration. Here, the nomadism of groups is not only a transformation of identity, but it also expresses a certain feminine life. The relevance of the study of the problems of the female lifeworld in social philosophy is due to the need to answer the question about the quality of functioning of postmodern society on the basis of freedom, justice, spirituality, wellbeing, etc. Violation of social identity, resulting from the loss of selfefficacy, leads to a weakening or even destruction of a family, marriage and family ties, interpersonal conflicts, suppression of gender-role identification. Consequently, migration is often a coverup, masking the loss of the spiritual resources of the inner world of family members, in particular women (mothers, wives). They declare 
the desire to earn money and are open to the nomadic movement. Life becomes tougher; women discover masculine gender-like traits, namely, autonomy, determination, activity, perseverance, energy, and in some cases aggression and autonomy from close emotional ties with their own family members (with parents, husband, and children).

Practical philosophy should look for those optimal models (for example, based on the Habermasian theory of communicative action, etc.) that contribute to balancing life, fostering nomadism and strengthening civic identity through education, enhancing culture, integrating the well-being of society. Thus, with the purpose of weakening the negative aspects of the modern migrationprocesses, which have been reflected in the state of the Ukrainian family, allpositive resources of the informational society should be launched and social communicationshould be strengthened for the rebirth of the basic values of the Ukrainianfamily. At the level of educational institutions, enlightening organisations, associationsand religious communities, the family dialogue should be intensified, since family lifeactivity is based on a psychoculture, which determines its social mobility. A dialoguewith parents should be conducted regarding the economic motivation for the activity - what is the good of earning money if emotional and spiritual relationshipswith children are lost? At the level of civil initiatives, Ukrainian governmental institutionsshould be encouraged to develop social projects directed at reducing the size andspeed of migration. International contracts regarding the legal aspects of migration areurgently needed in order to prevent the phenomenon of human trafficking. It is verydifficult to refresh spiritual values of the Ukrainian family without the state undertakingreforms inside Ukrainian society, which would include social and educationalprojects.

\section{SUMMARY}

The article analyzes interconnectivity of identity and nobility, the ways of their conceptualization and measurement. The crisis of Bauman's "pilgrim" as a modern identity project has begun with the intensification of the processes of globalization/fragmentation. The notion of "nomad" as the key subjectivity of contemporaneity (R. Braidotti, J. Deleuze) helps to understand the meaning of flexible and plural identity of human. Interconnectivity of identity/nomadism 
is the answer to all the diversity of socio-cultural challenges. The weakened Ukrainian civil identity is also a result of these world challenges. The transit to the values of European civilization involves the experience of joint liability. This new sensual fullness of the human lifeworld, which increases its civil responsibility, is a conceptual benchmark for the theoretical modeling of social reality.

\section{REFERENCES}

1. Deleuz G., Guattari F. Rhizome. Paris: Minuit, 1976. 269 p.

2. Брайдотти Р. Путем номадизма. Гендерные исследования. Харьков: ХЦГИ. 2000. № 4. С. 18-45.

3. Braidotti R. Patterns of Dissonance: A Study of Women and Contemporary Philosophy. Cambridge: Polity Press, 1991. 326 p.

4. Braidotti R. The Posthuman. Cambridge: Polity Press, 2013. $180 \mathrm{p}$.

5. Шюц А., Лукман Т. Структури життєсвіту; [пер. В.І. Кебуладзе]. Київ: Український Центр духовної культури, 2004. $560 \mathrm{c}$.

6. Хабермас Ю. Проблема легитимаџиии позднего капитализма. Москва: Праксис, 2010. 264 с.

7. Standing G. The Precariat: The New Dangerous Class. London: Bloomsbury Academic, 2011. 191 p.

8. Bauman Z. Retrotopia. Warszawa: Wydawnictwo naukowe PWN SA, 2018. S. 280.

9. Arendt H. Odpowiedzialność $i$ władza sadzenia, tłum. Wojciech Madej, Mieczysław Godyń Warszawa: Prószyński i S-ka, 2006. 352 s.

10.Герасимова Т. «Другим голосом»: в поисках утраченой истории. Гендерные исследования. Харьков: ХЦГИ. 2000. № 4. P. 227-246.

11.Гапон Н.П. Гендер у гуманітарному дискурсі філософсько-психологічний аналіз. Львів: Літопис. 310 с.

12. Lyubomirsky S., Dickerhoof R., Boehm J. K. \& Sheldon K. M. Becoming happier takes both a will and a proper way: An experimental longitudinal intervention to boost well-being. Emotion. 2011. No 11. P. 391-402. 
13. Seligman M. Authentic Happiness: Using the New Positive Psychology to Realize Your Potential for Lasting Fulfillment. New York: Free Press, 2004. 256 p.

\section{Information about the author:}

Hapon N. P.,

Doctor of Philosophie,

Professor at the Department of Psychology,

Ivan Franko National University of Lviv

1, Universytetska str., Lviv, 79000, Ukraine

Karas A. F.,

$\mathrm{PhD}$, Professor of Philosophy,

Chairperson of Philosophy Department,

Ivan Franko National University of Lviv

1, Universytetska str., Lviv, 79000, Ukraine 